\title{
Anticonvulsant effect of the ethanol extract of Caesalpinia pulcherrima (L.) Sw., Fabaceae, leaves
}

\author{
Dinesh Kumar, "Jitender Singh, Anupama Baghotia, Sunil Kumar
}

Institute of Pharmaceutical Sciences, Kurukshetra University, Kurukshetra, Haryana, India.

\begin{abstract}
RESUMO: "Efeito anticonvulsivante do extrato etanólico das folhas de Caesalpinia pulcherrima (L.) Sw., Fabaceae". Neste estudo, foi investigada o efeito anticonvulsivante do extrato etanólico das folhas de Caesalpinia pulcherrima (L.) Sw., Fabaceae (CPEE), utilizando convulsões induzidas por eletrochoque máximo (MES) e pentilenetetrazol (PTZ), em ratos e camundongos, nas doses 200 e $400 \mathrm{mg} / \mathrm{kg}$, i.p., respectivamente. Diazepam ( $3 \mathrm{mg} / \mathrm{kg}$, i.p.) foi usado como uma droga anticonvulsivante padrão. O extrato (CPEE) foi seguro até a dose de 4000 $\mathrm{mg} / \mathrm{kg}$ em camundongos, quando administrado por via intraperitoneal. O extrato de $400 \mathrm{mg} / \mathrm{kg}$ produziu efeito anticonvulsivante contra induções por PTZ de forma significativa $(p<0,01)$. Em modelo de convulsão induzida por MES, não houve alterações significativas no início, bem como a duração das crises de extensão dos membros pélvicos em relação ao controle na dose de $200 \mathrm{mg} /$ $\mathrm{kg}$ quando administrada por via intraperitoneal. No entanto, o extrato (CPEE, $400 \mathrm{mg} / \mathrm{kg}$ i.p.), de forma significativa $(p<0,01)$, atrasou o início, como também diminuiu a duração das crises de extensão dos membros posteriores (HLES) em relação ao controle. O extrato (CPEE) aumentou a percentagem de proteção dos animais em dose maior $(200 \mathrm{mg} / \mathrm{kg})$ em ambos os modelos. Os resultados do estudo sugerem que o extrato etanólico de folhas de Caesalpinia pulcherrima (L.) Sw. possui efeito anticonvulsivante.
\end{abstract}

Unitermos: Caesalpinia pulcherrima, extrato etanólico, efeito anticonvulsivante, máximo eletrochoque, pentlenetetrazol.

\begin{abstract}
In this study, ethanol extract of Caesalpinia pulcherrima (L.) Sw., Fabaceae, leaves (CPEE) was investigated for anticonvulsant effect against maximal electroshock (MES) and pentylenetetrazole (PTZ) induced seizures in rats and mice at dose levels 200 and $400 \mathrm{mg} /$ $\mathrm{kg}$, i.p. respectively. Diazepam (3 $\mathrm{mg} / \mathrm{kg}$, i.p.) was used as a standard anticonvulsant drug for comparison. CPEE was found to be safe up to the dose of $4000 \mathrm{mg} / \mathrm{kg}$ in mice, when administered intraperitoneally. The extract at $400 \mathrm{mg} / \mathrm{kg}$ dose produced significant $(p<0.01)$ anticonvulsant effect w.r.t. control against PTZ-induced clonic seizures. In MES-induced seizure model, there were no significant alterations in the onset as well as duration of hind limb extension seizures as compared to control at a dose of $200 \mathrm{mg} / \mathrm{kg}$ when administered intraperitoneally. However, the extract (CPEE, $400 \mathrm{mg} / \mathrm{kg}$ i.p.) significantly $(p<0.01)$ delayed the onset as well as decreased the duration of hind limb extension seizures (HLES) as compared to control. However, the extract, CPEE, percentage protection of the animals was increased at higher dose $(200 \mathrm{mg} / \mathrm{kg})$ in both the models. The results of the study suggest that ethanol extract of Caesalpinia pulcherrima (L.) Sw. leaves possess anticonvulsant effect.
\end{abstract}

Keywords: Caesalpinia pulcherrima, ethanol extract, anticonvulsant effect, maximal electroshock, pentylenetetrazole.

\section{INTRODUCTION}

Epilepsy is a common neurological disorder characterized by recurrentunprovoked seizures (Guidelines, 1993; Blume et al., 2001; James, 2001). Approximately 5\% of the world population develops epilepsy in their lifetime whereas overall prevalence rate of epilepsy in India is 5.59 per 1000 population (Sander \& Shorvon, 1996; Bharucha,
2003). Currently, many synthetic drugs like carbamazepine, ethosuximide, gabapentin, oxcarbazepine, phenobarbital, phenytoin, valproic acid, felbamate etc. are used as potent antiepileptic agents, but they are not free from marked side effects. Approximately $30 \%$ of the patients continue to have seizures with current antiepileptic drug therapy (Smith \& Bleck, 1991; Samren et al., 1997; Poole et al., 2000). Hence, there is a need to address a potent alternative 
as antiepileptic agent with minimal side effects. Several plants have been traditionally used in the treatment of epilepsy. A number of studies have been carried out on medicinal plants or plants based products and revealed good results when screened for anticonvulsant activity and many such plants are yet to be scientifically explored (Hosseinzadeh \& Parvardeh, 2004; Quintans-Júnior et al., 2008a,b).

Caesalpinia pulcherrima (L.) Sw., Fabaceae, is a leguminous, perennial large shrub or small tree and native of South America. In India, it is cultivated as ornamental plant. Commonly, it is known as Guletura, Gulutura (Hindi), Peacock flower, Barbados pride (English), Ratnagandhi (Sanskrit). It is a small tree, 3.7-4.3 $\mathrm{m}$ in height. Prickles are sparse on the branches, bark is grey in color. Leaves are abruptly bipinnate, leaflets in 13-20 pairs, $1.3-1.9 \mathrm{~cm}$ long. Flowers are red or yellow, fragrant. Flowering season of this plant starts from September to November and fruits from March to April.

Traditionally, the flowers, leaves, barks and roots of $C$. pulcherrima have been in clinical use in India since ancient times. Leaves are traditionally used as purgative, tonic, antipyretic and emmenagogue whereas roots have folkloric use in convulsions, intermittent fevers, lungs and skin diseases (Chatterjee \& Prakashi, 2006; Pullaiah, 2006). Moreover, the plants of genus Caesalpinia are reported to have anticonvulsant activity (Adesina, 1982). Therefore, based upon the reported uses of plants of genus Caesalpinia and traditional use of roots of $C$. pulcherrima in convulsions, $C$. pulcherrima leaves were selected for the investigation of anticonvulsant activity.

\section{MATERIAL AND METHODS}

Experimental protocols and procedures used in this study were approved by the Animal Ethics Committee of Kurukshetra University, Kurukshetra, India and conform to the guidelines of 'Committee for the Purpose of Control and Supervision on Experiments on Animals' [Reg. No. 562/02/a/CPCSEA].

\section{Procurement and identification of plant materials}

Fresh leaves of the plant were collected from University College, Kurukshetra University, Kurukshetra during the month of October 2008 and authentified by Dr. B. D. Vashistha, reader in Botany department of this university, as Caesalpinia pulcherrima (L.) Sw., Fabaceae. Voucher specimen (No. IPS/KUK/CP-1/2008) of the plant has been preserved in the herbarium of the Institute of Pharmaceutical Sciences, Kurukshetra University, Kurukshetra.

\section{Preparation of extract}

Leaves of Caesalpinia pulcherrima were dried in shade, powdered and stored in an air tight container at room temperature. Dried leaf powder (1690 g) was extracted with ethanol (95\%) using soxhlation method. The extract was concentrated to dryness using Rotary evaporator, giving yield as $14.12 \% \mathrm{w} / \mathrm{v}$ and preserved in a refrigerator. Aliquot portions of the ethanolic extract of Caesalpinia pulcherrima leaves (CPEE) were weighed and suspended in an appropriate volume of Tween $80(2 \% \mathrm{v} / \mathrm{v})$ for use on each day of our experiments. Doses of the extract were prepared according to body weight of the animals.

\section{Phytochemical screening}

Various phytochemical tests (Khandelwal, 2007; Kokate, 2005) were used to screen the Caesalpinia pulcherrima ethanol leaf extract.

\section{Animals}

Albino rats (125-140 g) and mice (25-32 g) of either sex were selected for experimental study. They were obtained from Haryana Agriculture University, Hisar, Haryana, India. The animals were kept and maintained under laboratory conditions of temperature $\left(21.5 \pm 2{ }^{\circ} \mathrm{C}\right)$, humidity $(60 \pm 1 \%)$ and $12 \mathrm{~h}$ light/dark cycle; and were allowed free access to food (standard pellet diet) and water ad libitum

\section{Acute toxicity study of the extract}

Adult albino mice (25-30 g) were divided into five groups each containing ten mice. The mice were fasted for $6 \mathrm{~h}$ with only access to water ad libitum before experimental study. Group I, II, III and IV animals were administered with various dose of CPEE i.e. 500, 1000, 2000, 3000 and $4000 \mathrm{mg} / \mathrm{kg}$. Group V received only vehicle (Tween $80,2 \% \mathrm{v} / \mathrm{v}$ in saline). All the doses and vehicle were administered intraperitoneally. The animals were observed for $72 \mathrm{~h}$ for mortality (Ravichandran et al., 2007; Sonavane et al., 2002).

\section{Evaluation of anticonvulsant activity}

\section{Pentylenetetrazole (PTZ)-induced seizure}

Albino mice of either sex (20-25 g) were selected for the study and divided into four groups of six animals each. Standard convulsant agent, pentylenetetrazole (PTZ, $80 \mathrm{mg} / \mathrm{kg}$ i.p.) was used to induce convulsions in the mice whereas Diazepam (DZP, $3.0 \mathrm{mg} / \mathrm{kg}$ i.p.) was used as reference anticonvulsant drug for comparison. Group I (control) received only vehicle. Groups II and III received CPEE at doses of 200 and $400 \mathrm{mg} / \mathrm{kg}$, respectively whereas Group IV was treated with DZP. All the treatments were done intraperitoneally (i.p.), $30 \mathrm{~min}$ before administration of PTZ. The animals were individually placed in plastic 
cases and observed immediately after PTZ injection for $30 \mathrm{~min}$. The onset and duration of myoclonic jerks/ convulsions as well as the percentage of protection against mortality were recorded (Hosseinzadeh \& Khosravan, 2002; Sayyah et al., 2002; Sonavane et al., 2002).

\section{MES-induced seizures}

Albino rats of either sex weighing between 100$150 \mathrm{mg} / \mathrm{kg}$ were used in this experiment. The electrical stimulus $(50 \mathrm{~mA}, 50 \mathrm{~Hz}, 1 \mathrm{~s}$ duration) was applied through ear-clip electrodes using electroconvulsiometer. Group I (control) animals received only vehicle (Tween 80) whereas Group II and III received CPEE at the doses of 200 and $400 \mathrm{mg} / \mathrm{kg}$, respectively. Group IV received reference anticonvulsant drug, DZP $3.0 \mathrm{mg} / \mathrm{kg}$. All the treatments were given intraperitoneally $30 \mathrm{~min}$ before electrical stimulus applied. Following induction of convulsions in the 'test' rats (due to electrical stimulus), the animals were observed for $30 \mathrm{~min}$ for signs of neurological deficits, especially hind limb tonic-clonic seizures or convulsions. Hind-limb tonic extensions of the rats were regarded as manifestations of seizures. The onset and duration of hind limb tonic-clonic seizures or convulsions as well as the percentage of protection against mortality were recorded (Hosseinzadeh \& Khosravan, 2002; Sayyah et al., 2002; Sonavane et al., 2002).

\section{Statistical analysis}

The Dunnett's test was employed for statistical comparison. In all the cases, value of $p<0.05$ was considered significant. All values have been presented as mean \pm S.E.

\section{RESULTS}

\section{Phytochemical screening}

Phytochemical screening of Caesalpinia pulcherrima (L.) Sw., Fabaceae, leaves ethanolic extract showed the presence of flavonoids, glycosides and tannins as shown in Table 1.

Table 1. Phytochemical screening of C. pulcherrima leaves ethanolic extract.

\begin{tabular}{ccc}
\hline $\begin{array}{c}\text { Tests for } \\
\text { phytoconstituents }\end{array}$ & Tests/Reagents & Inference \\
\hline Alkaloids & $\begin{array}{c}\text { Dragendorff's/Mayer's } \\
\text { reagent }\end{array}$ & -ve \\
Flavonoids & Lead acetate/ & $+\mathrm{ve}$ \\
& Sodium hydroxide & \\
Saponins & Foam test & $+\mathrm{ve}$ \\
Steroids & $\begin{array}{c}\text { Salkowski/Liebermann- } \\
\text { Burchard reaction }\end{array}$ & -ve \\
Tannins & Ferric chloride/ & $+\mathrm{ve}$ \\
& Bromine solution & \\
Cardiac glycosides & Keller-Kilani/Legal test & -ve \\
\hline
\end{tabular}

Table 2. Effect of CPEE on PTZ induced seizures in mice.

\begin{tabular}{|c|c|c|c|c|c|c|c|}
\hline Groups & $\begin{array}{l}\text { Treatment } \\
\text { (dose) }\end{array}$ & $\begin{array}{c}\text { Animals } \\
\text { used }\end{array}$ & $\begin{array}{c}\text { Onset of myoclonic } \\
\text { jerks (sec.) } \\
\text { Mean } \pm \text { SEM }\end{array}$ & $\begin{array}{c}\text { Duration of myoclonic } \\
\text { jerks (sec.) } \\
\text { Mean } \pm \text { SEM }\end{array}$ & $\begin{array}{l}\text { animals } \\
\text { convulsed }\end{array}$ & deaths & $\begin{array}{c}\% \text { Protection } \\
\text { against } \\
\text { mortality }\end{array}$ \\
\hline I & Control & 6 & $69.25 \pm 3.411$ & $15.62 \pm 1.13$ & $6 / 6$ & 6 & 0 \\
\hline II & $\begin{array}{c}\text { CPEE } \\
(200 \mathrm{mg} / \mathrm{kg})\end{array}$ & 6 & $92.28 \pm 2.826$ & $10.28 \pm 1.16$ & $6 / 6$ & 6 & 0 \\
\hline III & $\begin{array}{c}\text { CPEE } \\
(400 \mathrm{mg} / \mathrm{kg})\end{array}$ & 6 & $135.66 \pm 3.383^{*}$ & $4 \pm 0.23 *$ & $6 / 6$ & 4 & 33.3 \\
\hline IV & $\begin{array}{l}\text { Diazepam } \\
(3 \mathrm{mg} / \mathrm{kg})\end{array}$ & 6 & Absent & Absent & $3 * / 6$ & 1 & 83.3 \\
\hline
\end{tabular}

*Significance in relation to control: $p<0.01$. Six mice were used in each group and diazepam was taken as standard.

Table 3. Effect of CPEE on maximal electroshock (MES) induced seizures in rats.

\begin{tabular}{ccccccc}
\hline Groups & $\begin{array}{c}\text { Treatment } \\
\text { (dose) }\end{array}$ & $\begin{array}{c}\text { Onset of HLES } \\
(\text { sec.) Mean } \pm \text { SEM }\end{array}$ & $\begin{array}{c}\text { Duration of HLES } \\
\text { (sec.) Mean } \pm \text { SEM }\end{array}$ & $\begin{array}{c}\text { Number of rats } \\
\text { convulsed/ No. used }\end{array}$ & $\begin{array}{c}\text { Number } \\
\text { of deaths }\end{array}$ & $\begin{array}{c}\% \text { Protection } \\
\text { against } \\
\text { mortality }\end{array}$ \\
\hline I & Control & $12 \pm 0.91$ & $25.12 \pm 1.85$ & $6 / 6$ & 6 & 0 \\
II & CPAE $(200 \mathrm{mg} / \mathrm{kg})$ & $13 \pm 1.15$ & $17.25 \pm 1.56$ & $6 / 6$ & 5 & 25 \\
III & CPAE $(400 \mathrm{mg} / \mathrm{kg})$ & $23.33 \pm 2.4 *$ & $15.8 \pm 1.83^{*}$ & $2 * / 6$ & 3 & 2 \\
IV & Diazepam $(3 \mathrm{mg} / \mathrm{kg})$ & Absent & Absent & 75 \\
\hline
\end{tabular}

*Significance in relation to control: $p<0.01$. Diazepam was taken as control. 


\section{Acute toxicity study of the extract}

The CPEE was found to be safe at the escalated doses used and there was no mortality up to the dose of 4000 $\mathrm{mg} / \mathrm{kg}$ of extract when administered intraperitoneally.

\section{Pentylenetetrazol-induced seizures}

Single dose of Pentylenetetrazole (PTZ, $80 \mathrm{mg}$ / $\mathrm{kg}$ i.p.) produced hind-limb tonic seizures in all the six mice used. The plant extract (CPEE, $200 \mathrm{mg} / \mathrm{kg}$ i.p.), did not significantly delay the onset and decreased the duration of seizures. The plant extract (CPEE, $400 \mathrm{mg} / \mathrm{kg}$ i.p.), however, significantly $(p<0.01)$ delayed the onset of, and antagonized, PTZ-induced clonic seizures as well as decreased the duration of clonic convulsions. The CPEE $(400 \mathrm{mg} / \mathrm{kg}$, i.p.) exhibited $33.3 \%$ of protection against mortality whereas it was $83.3 \%$ in Diazepam treated group. The effect of CPEE on PTZ induced seizures in mice is shown in Table 2.

\section{Maximal electroshock (MES) induced seizures in rats}

The effects of CPEE on MES induced seizures in rats are summarized in Table 3. There were no significant alterations in the latency of convulsions as compared to control at a dose of $200 \mathrm{mg} / \mathrm{kg}$ of the extract. However, the extract (CPEE, $400 \mathrm{mg} / \mathrm{kg}$ i.p.) significantly $(p<0.01)$ delayed the onset as well as decreased the duration of hind limb extension seizures (HLES) as compared to control. The extract also exhibited 25 and $50 \%$ protection against mortality at doses of 200 and $400 \mathrm{mg} / \mathrm{kg}$ respectively whereas it was $75 \%$ in diazepam treated rats.

\section{DISCUSSION}

Some plants of genus Caesalpinia are reported to have anticonvulsant activity (Adesina, 1982). The present study was carried out based on the ethnomedicinal use of the Caesalpinia pulcherrima (L.) Sw., Fabaceae, in convulsions (Chatterjee \& Prakashi, 2006; Pullaiah, 2006).

The most popular and widely used animal seizure models are the traditional PTZ and MES tests. Prevention of seizures induced by PTZ in laboratory animals is the most commonly used preliminary screening test for characterizing potential anticonvulsant drugs. The MES test is considered to be a predictor of likely therapeutic efficacy against generalized tonic-clonic seizures. Generally, compounds with anticonvulsant activity in petit mal epilepsy are effective in PTZ induced seizure model (Löscher et al., 1991).

The extract (CPEE, 200mg/kg i.p.) slightly delayed the onset, decreased the duration of myoclonic seizures induced by PTZ, but mortality at this dose level was $100 \%$. The extract, however, significantly delayed the onset of as well as decreased the duration of myoclonic seizures induced by PTZ. The protection percentage of animals was also increased to $33 \%$ at a dose of $400 \mathrm{mg} /$ $\mathrm{kg}$. Therefore, the extract at $400 \mathrm{mg} / \mathrm{kg}$ dose produced significant $(p<0.01)$ anticonvulsant effect w.r.t. control against PTZ-induced clonic seizures.

In MES-induced seizure model, there were no significant alterations in the onset as well as duration of HLES as compared to control, suggesting that Caesalpinia pulcherrima extract does not have anticonvulsant effect at a dose of $200 \mathrm{mg} / \mathrm{kg}$ when administered intraperitoneally. However, the extract (CPEE, $400 \mathrm{mg} / \mathrm{kg}$ i.p.) significantly $(\mathrm{p}<0.01)$ delayed the onset as well as decreased the duration of hind limb extension seizures (HLES) as compared to control. Protection percentage of animals was also increased at higher dose level i.e. $400 \mathrm{mg} / \mathrm{kg}$.

Phytochemical screening of plant leaves ethanolic extract showed the presence of saponins, flavonoids and tannins. Based on this knowledge of the extract, it is not possible to attribute with certainty its anticonvulsant effect to one or several active principles among those detected in the screening. However, triterpenoidal saponins are reported to possess anticonvulsant activity in some experimental seizure models such as MES and PTZ (Chauhan et al., 1988; Kasture et al., 2002). Some flavonoids are also reported to have protective effects against PTZ, picrotoxin and NMDLA-induced convulsions (Johnston et al., 2004).

In conclusion, the results of the present study demonstrate, for the first time, that the ethanolic extract obtained from C. pulcherrima leaves possess anticonvulsant properties in PTZ and MES treated animals. Such pharmacological effects confirm and justify, at least in part, the popular traditional use of this plant to treat convulsions. However, the mechanism by which the plant extract exerts its anticonvulsant effect is still unclear. Therefore, this plant part must be further investigated to isolate the phytoconstituent responsible for anticonvulsant effect as well as its mechanism.

\section{REFERENCES}

Adesina SK 1982. Studies on some plants used as anticonvulsants in Amerindian and African traditional medicine. Fitoterapia 53: 147-162.

Bharucha NE 2003. Epidemiology of epilepsy in India. Epilepsia 44: 9-11.

Blume W, Lüders H, Mizrahi E, Tassinari C, Van Emde Boas W, Engel J 2001. Glossary of descriptive terminology for ictal semiology: report of the ILAE task force on classification and terminology. Epilepsia 42: 1212-1218.

Chatterjee A, Prakashi SC 2006. The treatise on Indian medicinal plants. New Delhi: NISCAIR.

Chauhan AK, Dobhal MP, Joshio BC 1988. A review of medicinal plant showing anticonvulsant activity. J Ethnopharmacol 22: 11-23. 
Guidelines for epidemiologic studies on epilepsy 1993. Commission on Epidemiology and Prognosis, International League Against Epilepsy. Epilepsia 34: 592-596.

Hosseinzadeh H, Khosravan V 2002. Anticonvulsant effects of aqueous and ethanolic extracts of Crocus sativus L. stigmas in mice. Arch Intern Med 5: 44-47.

Hosseinzadeh H, Parvardeh S 2004. Anticonvulsant effects of thymoquinone, the major constituent of Nigella sativa seeds in mice. Phytomedicine 11: 56-64.

James OM 2001. Drugs effective in the therapy of epilepsy. In: Joel GH, Lee EL, Alfred GG (Ed.). The pharmacological basis of therapeutics. 10. ed. New York: McGraw-Hill, p. 521-547.

Johnston GAR, Beart PM 2004. Flavonoids: Some of the wisdom of sage? Brit J Pharmacol 142: 809-810.

Kasture VS, Kasture SB, Chopde CT 2002. Anticonvulsive activity of Butea monosperma flowers inlaboratory animals. Pharmacol Biochem Be 72: 965-972.

Khandelwal KR 2007. Practical Pharmacognosy. Pune: Nirali Prakashan.

Kokate CK 2005. Practical Pharmacognosy. New Delhi: Vallabh Prakashan.

Löscher W, Fassbender CP, Nolting B 1991. The role of technical, biological and pharmacological factors in the laboratory evaluation of anticonvulsant drugs II. Maximal electroshock seizure models. Epilepsy Res 8: 79-94.

Poole K, Moran N, Bell G, Solomon J, Kendall S, McCarthy M, McCormick D, Nashef L, Johnson A, Sander J, Shorvon S 2000. Patients' perspectives on services for epilepsy: a survey of patient satisfaction, preferences and information provision in 2394 people with epilepsy. Seizure 9: 551-558.

Pullaiah T 2006. Encyclopaedia of world medicinal plants. New Delhi: Regency publications.

Quintans-Júnior LJ, Almeida JRGS, Lima JT, Nunes XP, Siqueira JS, Gomes de Oliveira LE, Almeida RN, F de Athayde-Filho P, Barbosa-Filho JM 2008a. Plants with anticonvulsant properties-a review. Rev Bras Farmacogn 18: 798-819.

Quintans-Júnior LJ, Souza TT, Leite BS, Lessa NMN, Bonjardim LR, Santos MRV, Alves PB, Blank AF, Antoniolli AR 2008b. Phythochemical screening and anticonvulsant activity of Cymbopogon winterianus Jowitt (Poaceae) leaf essential oil in rodents. Phytomedicine 15: 619-624.

Ravichandran V, Suresh B, Kumar S, MN, Elango K, Srinivasan R 2007. Antifertility activity of hydroalcoholic extract of Ailanthus excelsa (roxb): an ethnomedicines used by tribals of nilgiris region in Tamilnadu. J Ethnopharmacol 112: 189-191.

Samren EB, Van Duijn CM, Koch S, Hiilesmaa VK, Klepel H, Bardy AH, Mannagetta GB, Deichl AW, Gaily E, Granstrom ML, Meinardi H, Grobbee DE, Hofman A, Janz D, Lindhout D 1997. Maternal use of antiepileptic drugs and the risk of major congenital malformations: a joint European prospective study of human teratogenesis associated with maternal epilepsy. Epilepsia 38: 981990.

Sander JWAS, Shorvon SD 1996. Epidemiology of epilepsies. $J$ Neurol Neurosurg Psychiatry 61: 433-443.

Sayyah M, Valizadeh J, Kamalinejad M 2002. Anticonvulsant activity of the leaf essential oil of Laurus nobilis against pentylenetetrazole and maximal electroshock-induced seizures. Phytomedicine 9: 212-216.

Smith MC, Bleck TP 1991. Convulsive Disorders: Toxicity of anticonvulsants. Clin Neuropharmacol 14: 97-115.

Sonavane GS, Palekar RC, Kasture VS, Kasture SB 2002. Anticonvulsant and behavioral actions of Myristica fragrans seeds. Indian J Pharmacol 34: 332-338. 